\title{
Drug Metal Ion Interaction: Kinetics and Mechanism of Interaction of cis-Bis(oxalato)diaquochromium(III) Ion with Ampicillin in Aqueous Medium
}

\author{
BHARATI BEHERA and JASHODA BEHERA* \\ Department of Chemistry, Utkal University, \\ Vani Vihar, Bhubaneswar-751004, Odisha, India \\ jbeherachemistry@gmail.com
}

Received 12 July 2017 / Accepted 20 July 2017

\begin{abstract}
The kinetics of anation of cis- $\left[\mathrm{Cr}\left(\mathrm{C}_{2} \mathrm{O}_{4}\right)_{2}\left(\mathrm{H}_{2} \mathrm{O}\right)_{2}\right]^{-}$by ampicillin have been investigated in aqueous medium over the range $3.0 \leq \mathrm{pH} \leq 5.0,1.50 \times 10^{-2} \mathrm{~mol} \mathrm{dm}^{-3} \leq[\mathrm{AMP}] \leq 4.50 \times 10^{-2} \mathrm{~mol} \mathrm{dm}^{-3}$, $I=0.3 \mathrm{~mol} \mathrm{dm}^{-3}\left(\mathrm{KNO}_{3}\right)$ and at temperature $35^{\circ} \mathrm{C} \leq \mathrm{t} \leq 50{ }^{\circ} \mathrm{C}$. The reaction takes place through an $I_{a}$ mechanism. The rate of reaction is found to increase with increase in $\left[\mathrm{H}^{+}\right]$and [AMP-Na]. The activation parameters $\Delta \mathrm{H}^{\ddagger}$ and $\Delta \mathrm{S}^{\ddagger}$ are found to be $42.4 \pm 2.5$ and $-176.6 \pm 8.1$ respectively. The negative values of activation entropies $\left(\Delta \mathrm{S}^{\neq}\right)$indicate a more ordered activated complex than the reactants and the reactions are slow. The positive values of activation enthalpy $\left(\Delta \mathrm{H}^{\ddagger}\right)$ shows that the decomposition process is endothermic. The product was isolated as $\left[\mathrm{Cr}_{2}\left(\mathrm{C}_{2} \mathrm{O}_{4}\right)_{4}(\mathrm{AMP})\right] \cdot 2 \mathrm{H}_{2} \mathrm{O}$ which was confirmed by FTIR and AAS method. The antimicrobacterial activities of the complex was tested against some kind of bacteria comparable with the ampicillin free drug.
\end{abstract}

Keywords: Cr(III)complex, Ampicillin, Substitution reaction, Kinetic study, Elemental analysis, Antimicrobial activity

\section{Introduction}

$\beta$-Lactam antibiotics constitute a broad class of antimicrobial agents, applied for systemic therapy and gastric or intestinal infections ${ }^{1}$. This includes respiratory tract infections, urinary tract infections, meningitis, salmonella infections and endocarditis. It works by stopping the growth of bacteria. Like all antibiotics, it is not useful for the treatment of viral infections.

Ampicillin belongs to the penicillin group of beta-lactam antibiotics and is part of the aminopenicillin family. It is able to penetrate Gram-positive and some Gram-negative bacteria. It differs from penicillin $\mathrm{G}$, or benzylpenicillin, only by the presence of an amino group, that helps the drug penetrate the outer membrane of Gram-negative bacteria. Its spectrum of activity is enhanced by co-administration of sulbactam, a drug that inhibits beta lactamase, an enzyme produced by bacteria to inactivate ampicillin and related antibiotics ${ }^{2,3}$. 
Ampicillin acts as an irreversible inhibitor of the enzyme transpeptidase, which is needed by bacteria to make their cell walls. It inhibits the third and final stage of bacterial cell wall synthesis in binary fission, which ultimately leads to cell lysis; therefore ampicillin is usually bacteriolytic ${ }^{4}$.

The study of metal complexes with drugs as ligands is very interesting because of the metal action enhanced the activity of the drug ${ }^{5,6}$. Chromium is an essential nutrient required for glucose and lipid metabolism ${ }^{7}$ and improves insulin sensitivity by enhancing intracellular signaling ${ }^{8}$. The kinetics and mechanism of the substitution of $\left[\mathrm{Cr}(\mathrm{Ox})_{2}\left(\mathrm{H}_{2} \mathrm{O}\right)_{2}\right]^{-}$with oxalates, periodate and peptides have been reported ${ }^{9,10}$. In the species $\left[\mathrm{Cr}(\mathrm{Ox})_{2}\left(\mathrm{H}_{2} \mathrm{O}\right)_{2}\right]^{-}$, generally the oxalate groups are resistant against substitution or dissociation ${ }^{11}$. The substitution reactions of diaquabisoxalatochromate(III) have attracted attention because of the biological importance of $\mathrm{Cr}(\mathrm{III})$. The kinetics and mechanism of reaction of $\mathrm{Cr}$ (III) complex with $L$-Dopa, an antiparkinson drug has also been studied ${ }^{12}$. The parent drug is less efficient than the drug in the metal complex ${ }^{13}$. All antibiotics need not contain metal ions for their biological activities whereas some antibiotics $\mathrm{do}^{14}$. Several workers ${ }^{15-19}$ reported on the study of chromium(III) complexes as deficiency of chromium(III) ion results in an impairment of intravenous glucose tolerance and diabetics like symptoms in man and animals. The stability of metal complexes with medicinal drugs play a major role in biological and chemical activity ${ }^{20,21}$.

As both the metal $\mathrm{Cr}(\mathrm{III})$ and the drug ampicillin are very important in biological system, the interaction of diaquabisoxalatochromate(III) with ampicillin sodium have been studied. Also the complexation reaction of both diaquabisoxalato chromate(III) and ampicillin sodium would help to explore the possibility of direct substitution of the drug at the $\mathrm{Cr}^{\text {III }}$ center by $\mathrm{Cr}^{-} \mathrm{OH}_{2}$ bond breaking ${ }^{22,23}$. $\mathrm{Cr}(\mathrm{III})$ ampicillin complex has also been isolated which is characterised by different technique.

\section{Experimental}

For kinetic mesurements, Agilent Cary $100 \mathrm{UV}-\mathrm{Vis}$ spectrophotometer and for $\mathrm{pH}$ measurements, electronics India pH-meter model - 101 were used. Ampicillin (A.R, AMP$\mathrm{Na}$ salt) was received from SRL. Other chemicals are of analytical grade (Merck). All solutions were prepared in distilled water. The stock solution of $\mathrm{Cr}(\mathrm{III})$ was prepared by dissolving accurate amount of $\left[\mathrm{Cr}\left(\mathrm{C}_{2} \mathrm{O}_{4}\right)_{2}\left(\mathrm{H}_{2} \mathrm{O}\right)_{2}\right]$ in a definite volume of water. $\mathrm{KNO}_{3}$ was used to maintain constant ionic strength. The $\mathrm{Cr}(\mathrm{III})$ concentration was determined after oxidation the $\mathrm{Cr}(\mathrm{III})$ complex to $\mathrm{CrO}_{4}{ }^{2-}$ followed by iodometric method. Solutions were prepared in doubly distilled water.

\section{Synthesis of $\mathrm{K}\left[\mathrm{Cr}\left(\mathrm{C}_{2} \mathrm{O}_{4}\right)_{2}\left(\mathrm{H}_{2} \mathrm{O}\right)_{2}\right]$ complex}

About $12 \mathrm{~g}$ of oxalic acid dihydrate was taken with $4 \mathrm{~g}$ of potassium dichromate and they were ground into fine powder ${ }^{24}$. Once mixing in the mortar was complete it was transferred to a $150 \mathrm{~cm}^{3}$ beaker containing about 5 drops of water. The damp powder was then covered with a watch glass before a vigorous reaction occurred. Large volumes of carbon dioxide evolved until only the dark coloured semi-solid remained. $20 \mathrm{~cm}^{3}$ of alcohol was added to the solution which was being continually warmed. After stirring the solution, a crystalline product eventually resulted. The product was filtered on a Buchner funnel, washed with alcohol and dried and stored in a vacuum desiccator. The product Cis$\mathrm{K}\left[\mathrm{Cr}\left(\mathrm{C}_{2} \mathrm{O}_{4}\right)_{2}\left(\mathrm{H}_{2} \mathrm{O}\right)_{2}\right] \cdot 2 \mathrm{H}_{2} \mathrm{O}$ appears almost black in diffuse day light or deep green in artificial light. The product was purified by recrystallisation from water. The amount of $\mathrm{Cr}$ was further checked estimated by atomic absorption spectroscopy (AAS). The $\mathrm{Cr}$ (III) analysis by iodometry and AAS agreed satisfactorily. 


\section{Kinetic measurements}

For the kinetic measurements, the ionic strength was maintained with $\mathrm{KNO}_{3}$ solution. The solution of the drug at the desired $\mathrm{pH}$ (adjusted with $\mathrm{NaOH} / \mathrm{HClO}_{4}$ of known strength) was thermally equilibrated at a given temperature. Then, the required amount of thermally equilibrated $\mathrm{Cr}$ (III) solution was added to the drug solution and the change in absorbance was monitored at $350 \mathrm{~nm}$. Pseudo-first order conditions were maintained throughout these experiments by using a large excess of AMP-Na. In this experiment the ratios of [Cr(III)]:[AMP-Na] were 1:5, 1:7.5, 1:10, 1:12.5 and 1:15. The rate constant $\mathrm{k}_{\text {obs }}$ were obtained from the slopes of $\ln \left(\mathrm{A}_{\infty}-\mathrm{A}_{\mathrm{t}}\right)$ versus time plots; i.e. $\ln \left(\mathrm{A}_{\infty}-\mathrm{A}_{\mathrm{t}}\right)=\ln \left(\mathrm{A}_{\infty}-\mathrm{A}_{0}\right)-\mathrm{k}_{\mathrm{obs}} \mathrm{t}$

Where $A_{0}, A_{t}$ and $A_{\infty}$ are the absorbances at beginning, at time $t$ and for complete reaction, respectively. The correlation coefficients of plots (used to determine $k_{\text {obs }}$ ) were found to be 0.98 in most cases.

\section{Results and Discussion}

\section{Stoichiometry and product analysis}

$\mathrm{Cr}$ (III) complex shows the $\lambda_{\max }$ at $415 \mathrm{~nm}$ and $565 \mathrm{~nm}$ (Figure 1). On addition of the drug at $\mathrm{pH}=5$ absorbance increased with time. There is a clear indication of increased absorbance at 350 $\mathrm{nm}$ indicating substitution of the coordinated $\mathrm{H}_{2} \mathrm{O}$ by ampicillin. The rate of substitution reaction at different concentrations of the drug $\left(1.50 \times 10^{-2} \mathrm{~mol} \mathrm{dm}^{-3} \leq[\mathrm{AMP}] \leq 4.50 \times 10^{-2}, 3.0 \leq\right.$ $\mathrm{pH} \leq 5.0,35^{\circ} \mathrm{C} \leq \mathrm{T} \leq 50^{\circ} \mathrm{C}$ and $\mathrm{I}=0.3 \mathrm{~mol} \mathrm{dm}^{-3}$ ) has been studied by spectrophotometry.

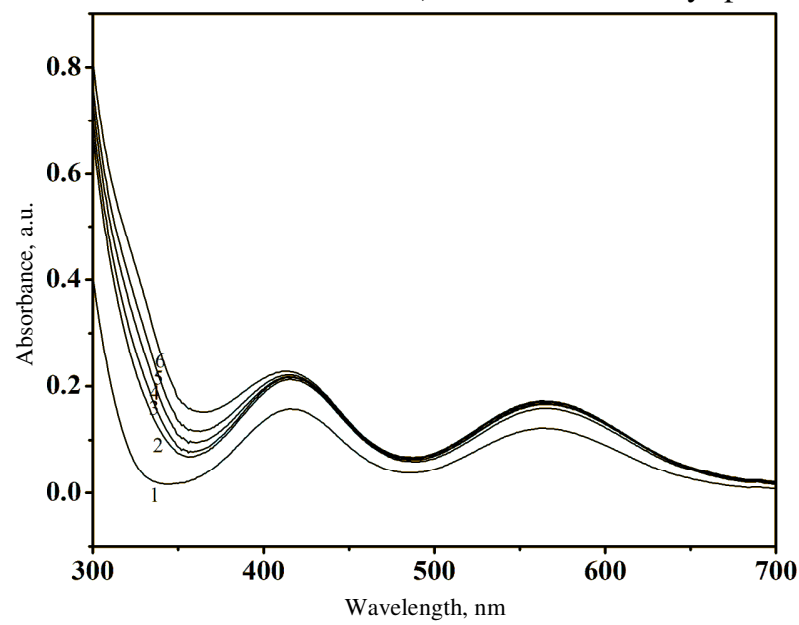

Figure 1. Time dependent spectral scans for $\mathrm{Cr}(\mathrm{III})+\mathrm{AMP}-\mathrm{Na}$. Cis- $\left[\mathrm{Cr}\left(\mathrm{C}_{2} \mathrm{O}_{4}\right)_{2}\left(\mathrm{H}_{2} \mathrm{O}\right)_{2}\right]_{\mathrm{T}}^{-}$ $=3.0 \times 10^{-3} \mathrm{~mol} \mathrm{dm}^{-3},\left[\right.$ AMP-Na] $=3.0 \times 10^{-2} \mathrm{~mol} \mathrm{dm}^{-3},[\mathrm{Cr}]:[\mathrm{AMP}]=1: 10, \mathrm{pH}=5.0, \mathrm{I}=0.3$ mol dm$~_{-3}$, (1) complex alone, (2-6) at different time intervals, (2) after immediate mixing, (3) after $15 \mathrm{~min},(4)$ after $30 \mathrm{~min},(5)$ after $45 \mathrm{~min},(6)$ after $1 \mathrm{~h}$

\section{Effect of $\mathrm{pH}$ on reaction rate}

The reaction was studied at varying $\mathrm{pH}$ (3.0-5.0) keeping $\mathrm{I}=0.3 \mathrm{~mol} \mathrm{dm}^{-3}$ and cis$\left[\mathrm{Cr}\left(\mathrm{C}_{2} \mathrm{O}_{4}\right)_{2}\left(\mathrm{OH}_{2}\right)_{2}\right]^{-}=3.0 \times 10^{-3} \mathrm{~mol} \mathrm{dm}$ at all temperatures. With the increase of $\mathrm{pH}, \mathrm{k}_{\mathrm{obs}}$ values increased (Table 1). To explain the $\left[\mathrm{H}^{+}\right]$dependence on the reaction rate, it is necessary to consider the protonation equilibria of AMP-Na as the aqua complex irtually is not likely to undergo acid-base dissociation $\left(p K_{1}=7.1\right)$ under the experimental condition ${ }^{25}$. 
Table 1. Rate constants for substitution of ampicillin sodium salt (AMP-Na) in cis- $\left[\mathrm{Cr}\left(\mathrm{C}_{2} \mathrm{O}_{4}\right)_{2}\right.$ $\left.\left(\mathrm{OH}_{2}\right)_{2}\right]^{-}$at all temperatures, $\mathrm{I}=0.3 \mathrm{~mol} \mathrm{dm}^{-3}$ and cis- $\left[\mathrm{Cr}\left(\mathrm{C}_{2} \mathrm{O}_{4}\right)_{2}\left(\mathrm{OH}_{2}\right)_{2}\right]^{-}=3.0 \times 10^{-3} \mathrm{~mol} \mathrm{dm}^{-3}$

\begin{tabular}{cccccc}
\hline \multirow{2}{*}{$\mathrm{pH}$} & \multirow{2}{*}{$0^{2}[\mathrm{AMP}-\mathrm{Na}] / \mathrm{mol} \mathrm{dm}^{-3}$} & \multicolumn{4}{c}{$10^{4} \mathrm{k}_{\mathrm{obs}} / \mathrm{s}^{-1}$} \\
\cline { 3 - 6 } $\mathrm{pH}=3.0$ & 1.50 & 0.26 & 0.29 & 0.34 & 0.51 \\
& 2.25 & 0.35 & 0.40 & 0.51 & 0.69 \\
& 3.00 & 0.44 & 0.51 & 0.62 & 0.87 \\
& 3.75 & 0.55 & 0.63 & 0.75 & 1.15 \\
$\mathrm{pH}=3.5$ & 4.50 & 0.66 & 0.74 & 0.85 & 1.32 \\
& 1.50 & 0.29 & 0.33 & 0.41 & 0.63 \\
& 2.25 & 0.42 & 0.46 & 0.56 & 0.88 \\
& 3.00 & 0.51 & 0.62 & 0.72 & 1.12 \\
$\mathrm{pH}=4$ & 3.75 & 0.60 & 0.69 & 0.91 & 1.32 \\
& 4.50 & 0.71 & 0.81 & 1.02 & 1.62 \\
& 1.50 & 0.33 & 0.38 & 0.52 & 0.77 \\
& 2.25 & 0.48 & 0.57 & 0.75 & 1.16 \\
$\mathrm{pH}=4.5$ & 3.00 & 0.57 & 0.69 & 0.89 & 1.41 \\
& 3.75 & 0.67 & 0.81 & 1.09 & 1.59 \\
& 4.50 & 0.81 & 0.89 & 1.29 & 1.85 \\
& 1.50 & 0.39 & 0.45 & 0.65 & 1.02 \\
& 2.25 & 0.56 & 0.61 & 0.92 & 1.35 \\
& 3.00 & 0.69 & 0.79 & 1.09 & 1.64 \\
$\mathrm{pH}=5.0$ & 3.75 & 0.79 & 0.93 & 1.35 & 2.12 \\
& 4.50 & 0.95 & 1.05 & 1.52 & 2.45 \\
& 1.50 & 0.47 & 0.48 & 0.78 & 1.22 \\
& 2.25 & 0.66 & 0.71 & 1.12 & 1.69 \\
& 3.00 & 0.78 & 0.86 & 1.29 & 2.02 \\
& 3.75 & 0.96 & 0.97 & 1.51 & 2.47 \\
& 4.50 & 1.17 & 1.15 & 1.89 & 2.91 \\
\hline & & & & &
\end{tabular}

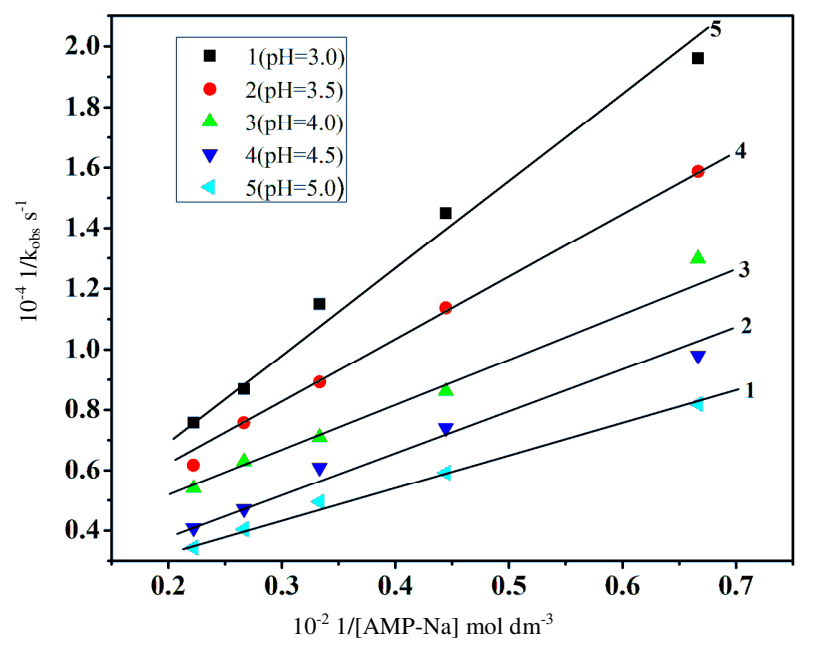

Figure 2. Plot of $1 / \mathrm{k}_{\text {obs }}$ versus $1 /[\mathrm{AMP}-\mathrm{Na}]$ at $50{ }^{\circ} \mathrm{C}$, cis- $\left[\mathrm{Cr}\left(\mathrm{C}_{2} \mathrm{O}_{4}\right)_{2}\left(\mathrm{H}_{2} \mathrm{O}\right)_{2}\right]_{\mathrm{T}}{ }_{\mathrm{T}}=3.0 \times 10^{-3} \mathrm{~mol}$ $\mathrm{dm}^{-3}, \mathrm{I}=0.3 \mathrm{~mol} \mathrm{dm}{ }^{-3}, 1=\mathrm{pH} 3.0,2=\mathrm{pH} 3.5,3=\mathrm{pH} 4.0,4=\mathrm{pH} 4.5,5=\mathrm{pH} 5.0$ 


\section{Effect of drug}

The concentration of [AMP] was varied from $1.50 \times 10^{-2}$ to $4.50 \times 10^{-2} \mathrm{~mol} \mathrm{dm}^{-3}$ at constant cis- $\left[\mathrm{Cr}\left(\mathrm{C}_{2} \mathrm{O}_{4}\right)_{2}\left(\mathrm{OH}_{2}\right)_{2}\right]^{-}$. As [AMP] increases, $\mathrm{k}_{\text {obs }}$ increases in a non linear fashion which indicates that outer sphere complex was formed between cis- $\left[\mathrm{Cr}\left(\mathrm{C}_{2} \mathrm{O}_{4}\right)_{2}\left(\mathrm{OH}_{2}\right)_{2}\right]^{-}$and AMP. The $1 / \mathrm{k}_{\text {obs }} v s .1 /[\mathrm{AMP}-\mathrm{Na}]-$ plot accordingly were linear with positive intercept on the rate axis (Figure 2).

\section{Reaction mechanism}

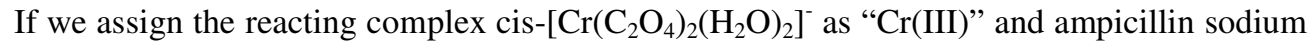
salt as " $\mathrm{A}$ ", then the complexation reaction may be denoted to the following steps:

$$
\mathrm{A}^{-}+\mathrm{H}^{+} \stackrel{\mathrm{K}_{\mathrm{d}}}{\rightleftharpoons} \mathrm{AH}
$$

Where $\mathrm{K}_{\mathrm{d}}$ is the dissociative rate constant and can be expressed as

$$
K_{d}=\frac{[A H]_{e}}{\left[A^{-}\right]_{e}\left[H^{+}\right]_{e}}
$$

At any time in the reaction, the total concentration of ampicillin ion that is $\left[\mathrm{A}^{-}\right]_{\mathrm{T}}$ can be shown as

$$
\begin{aligned}
{\left[\mathrm{A}^{-}\right]_{\mathrm{T}} } & =\left[\mathrm{A}^{-}\right]_{\mathrm{e}}+[\mathrm{AH}]_{\mathrm{e}} \\
& =\left[\mathrm{A}^{-}\right]_{\mathrm{e}}+\mathrm{K}_{\mathrm{d}}\left[\mathrm{A}^{-}\right]_{\mathrm{e}}\left[\mathrm{H}^{+}\right]_{\mathrm{e}}=\left[\mathrm{A}^{-}\right]_{\mathrm{e}}\left\{1+\mathrm{K}_{\mathrm{d}}\left[\mathrm{H}^{+}\right]_{\mathrm{e}}\right.
\end{aligned}
$$

From Eq. 4, $\left[\mathrm{A}^{-}\right]_{\mathrm{e}}$ can be expressed as

$$
\begin{gathered}
{\left[A^{-}\right]_{e}=\frac{\left[A^{-}\right]_{T}}{1+K_{d}\left[H^{+}\right]_{e}}} \\
\mathrm{Cr}(\mathrm{III})+\mathrm{A}^{-} \stackrel{\mathrm{K}_{\mathrm{IP}}}{\longrightarrow} \mathrm{Cr}(\mathrm{III}) \cdot \mathrm{A}^{-} \stackrel{\mathrm{k}_{\mathrm{an}}}{\longrightarrow} \text { products }
\end{gathered}
$$

$$
\text { Rate }=\mathrm{k}_{\mathrm{an}}[\mathrm{I} . \mathrm{P}]_{\mathrm{e}}=\mathrm{k}_{\mathrm{an}} \mathrm{K}_{\mathrm{IP}}[\mathrm{Cr}(\mathrm{III})]_{\mathrm{e}}\left[\mathrm{A}^{-}\right]_{\mathrm{e}}
$$

At any moment in the reaction, the total concentration of $\mathrm{Cr}(\mathrm{III})$ that is $[\mathrm{Cr}(\mathrm{III})]_{\mathrm{T}}$ can be taken as

$$
\begin{aligned}
{[\mathrm{Cr}(\mathrm{III})]_{\mathrm{T}} } & =[\mathrm{Cr}(\mathrm{III})]_{\mathrm{e}}+[\mathrm{II} . \mathrm{P}]_{\mathrm{e}}=[\mathrm{Cr}(\mathrm{III})]_{\mathrm{e}}+\mathrm{K}_{\mathrm{IP}}[\mathrm{Cr}(\mathrm{III})]_{\mathrm{e}}\left[\mathrm{A}^{-}\right]_{\mathrm{e}} \\
= & {[\mathrm{Cr}(\mathrm{III})]_{\mathrm{f}}\left\{1+\mathrm{K}_{\mathrm{IP}}\left[\mathrm{A}^{-}\right]_{\mathrm{e}}\right\}[\mathrm{Cr}(\mathrm{III})]_{\mathrm{e}}=[\mathrm{Cr}(\mathrm{III})]_{\mathrm{T}} /\left\{1+\mathrm{K}_{\mathrm{IP}}\left[\mathrm{A}^{-}\right]_{\mathrm{e}}\right\} }
\end{aligned}
$$

Putting the value of $[\mathrm{Cr}(\mathrm{III})]_{\mathrm{T}}$ from Eq. 7 to Eq. 6, we get Eq. 8

$$
\begin{gathered}
\text { Rate }=\frac{\mathrm{k}_{\mathrm{an}} \mathrm{K}_{\mathrm{IP}}\left[\mathrm{Cr}(\mathrm{III}]_{\mathrm{T}}\right.}{\left\{1+\mathrm{K}_{\mathrm{IP}}\left[\mathrm{A}^{-}\right]_{\mathrm{e}}\right\}} \frac{\left[\mathrm{A}^{-}\right]_{\mathrm{T}}}{\left\{1+\mathrm{k}_{\mathrm{d}}\left[\mathrm{H}^{+}\right]\right\}} \\
\text {Rate }=\frac{\mathrm{k}_{\mathrm{an}} \mathrm{K}_{\mathrm{IP}}\left[\mathrm{Cr}(\mathrm{III}]_{\mathrm{T}}\left[\mathrm{A}^{-]}\right]_{\mathrm{T}}\right.}{\left\{1+\mathrm{K}_{\mathrm{d}}\left[\mathrm{H}^{+}\right]+\mathrm{K}_{\mathrm{IP}}\left[\mathrm{A}^{-}\right]_{\mathrm{T}}\right\}} \\
\text { Rate }=\mathrm{k}_{\mathrm{obs}}[\mathrm{Cr}(\mathrm{III})]_{\mathrm{T}} \\
\mathrm{k}_{\mathrm{obs}}=\frac{\mathrm{k}_{\mathrm{an}} \mathrm{K}_{\mathrm{IP}}\left[\mathrm{A}^{-}\right]_{\mathrm{T}}}{\left\{1+\mathrm{K}_{\mathrm{d}}\left[\mathrm{H}^{+}\right]+\mathrm{KIP}\left[\mathrm{A}^{-}\right]_{\mathrm{T}}\right\}}
\end{gathered}
$$

The Eq. 11 can be linearised to equation 12

$$
\frac{1}{\mathrm{k}_{\mathrm{obs}}}=\frac{\left\{1+\mathrm{K}_{\mathrm{d}}\left[\mathrm{H}^{+}\right]\right\}}{\mathrm{k}_{\mathrm{an}} \mathrm{K}_{\mathrm{IP}}} \quad \frac{1}{\left[\mathrm{~A}^{-}\right]_{\mathrm{T}}} \quad \frac{1}{\mathrm{~K}_{\mathrm{an}}}
$$


Using Eq. 12, $\mathrm{k}_{\mathrm{an}}, \mathrm{K}_{\mathrm{IP}}$ and observed rate constant values were calculated. The high negative values of activation entropies $\left(\Delta \mathrm{S}^{\ddagger}\right)$ indicate associative mechanism $(\mathrm{A})^{26}$. The relative small values of activation enthalpy $\left(\Delta \mathrm{H}^{\ddagger}\right)$ also support such a mechanism (Table 2).

\section{Isolation of the product}

A solution of $0.001 \mathrm{~mol} \mathrm{dm}^{-3}$ cis- $\left[\mathrm{Cr}\left(\mathrm{C}_{2} \mathrm{O}_{4}\right)_{2}\left(\mathrm{H}_{2} \mathrm{O}\right)_{2}\right]^{-}$and $0.0012 \mathrm{~mol} \mathrm{dm}^{-3}$ AMP at pH 5.0 were dissolved in a small volume of water and heated in a thermostat for 5-6 hours at $50{ }^{\circ} \mathrm{C}$. Most of the solution was evaporated when deep gray coloured solid product appeared. It was recrystallised from water, washed with ethanol and ether and dried in a vacuum desiccator.

\section{Broad chemical analysis of the product}

Elemental analysis viz. C, H, N, S including $\mathrm{Cr}$ done through AAS shows that the percentage of carbon $(30.36 \%)$, hydrogen $(3.90 \%)$, nitrogen $(5.72 \%)$, sulphur $(2.61 \%)$ and chromium $(11.10 \%)$ were corresponding to the theoretical values of the complex (Table 3). Hence C, H, N, $\mathrm{S}$ and $\mathrm{Cr}$ percentage data is in agreement with the proposed structure (Figure 3).

Table 2. Thermodynamic parameters

\begin{tabular}{cc}
\hline Temp. $/{ }^{\circ} \mathrm{C}$ & $10^{4} k_{\mathrm{an}} / \mathrm{s}^{-1}$ \\
\hline 35 & $2.68 \pm 0.51$ \\
40 & $3.14 \pm 0.54$ \\
45 & $4.18 \pm 1.73$ \\
50 & $6.48 \pm 4.36$ \\
\hline$\Delta H^{\ddagger}\left(\mathrm{kJ} \mathrm{mol}^{-1}\right)=$ & $42.4 \pm 2.5$ \\
$\Delta S^{\ddagger}\left(\mathrm{J} \mathrm{K}^{-1} \mathrm{~mol}^{-1}\right)=$ & $-176.6 \pm 8.1$ \\
\hline
\end{tabular}

Table 3. Percentage of the elements in the ampicillin chromium complex

\begin{tabular}{cc}
\hline Element & $\%$ Present \\
\hline Carbon & $31.68(30.36)^{*}$ \\
Hydrogen & $2.42(3.90)^{*}$ \\
Nitrogen & $4.62(5.72)^{*}$ \\
Sulphur & $3.52(2.61)^{*}$ \\
Chromium & $11.4(11.10)^{*}$ \\
\hline \multicolumn{2}{c}{ *Represents theoretical values }
\end{tabular}

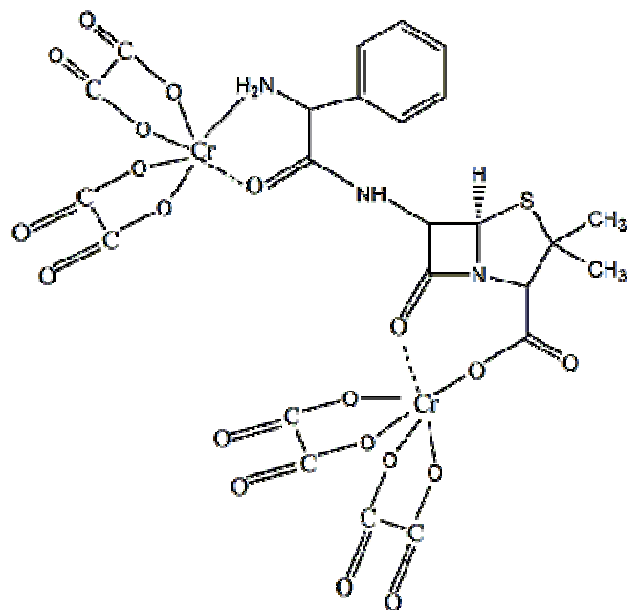

Figure 3. Tentative structure of ampicillinCr(III) complex

\section{Conformation of the product by IR spectra}

The IR spectra of ampicillin (Figure 4) shows characteristic bands at $3347 \mathrm{~cm}^{-1}$ due to $v(\mathrm{~N}-\mathrm{H})$ of imino group and $v\left(\mathrm{NH}_{2}\right)$ group ${ }^{27}$. The absorption bands at 3029,2962 and $2926 \mathrm{~cm}^{-1}$ in ampicillin free ligand are assigned to $\mathrm{C}-\mathrm{H}$ stretching vibrations of aromatic and aliphatic moieties ${ }^{28}, 1758$ and $1673 \mathrm{~cm}^{-1}$ bands are due to $v(\mathrm{C}=\mathrm{O})$ of $\beta$-lactam and amide carbonyl group $^{29}$. The vibration bands at 1605 and $1370 \mathrm{~cm}^{-1}$ are assigned to asymmetric and symmetric stretching vibration of the carboxylate group ${ }^{27-29}$, respectively. The low frequencies within the range of $914-535 \mathrm{~cm}^{-1}$ are assigned to out-of-plane bending of the ring $\mathrm{C}-\mathrm{H}$ bands, while the in-plane bending bands are located within $1326-1091 \mathrm{~cm}^{-1}$ region. The characteristic $\mathrm{C}=\mathrm{C}$ skeletal stretching vibrations lead to a group of bands within the $1605-1453 \mathrm{~cm}^{-1}$ region ${ }^{30}$.

It has been observed that there are some changes in frequencies and intensities of the IR bands of the product complex (Figure 5) in comparison to ampicillin free ligand. The coordination mode for $\mathrm{Cr}^{\mathrm{III}}$ ions towards ampicillin ligand show that the vibration bands of $v$ 
$(\mathrm{C}=\mathrm{O})$ amido and $v(\mathrm{~N}-\mathrm{H})$ imino groups are shifted to lower wave numbers which suggest that the coordination of $\mathrm{Cr}(\mathrm{III})$ to ampicillin ligand occurs through $(\mathrm{C}=\mathrm{O})$ amido and $(\mathrm{N}-\mathrm{H})$ imino groups. The broad (shoulder) absorption band at $3457 \mathrm{~cm}^{-1}$ is assigned to $v(\mathrm{O}-\mathrm{H})$ of the hydrated water molecules ${ }^{30}$.

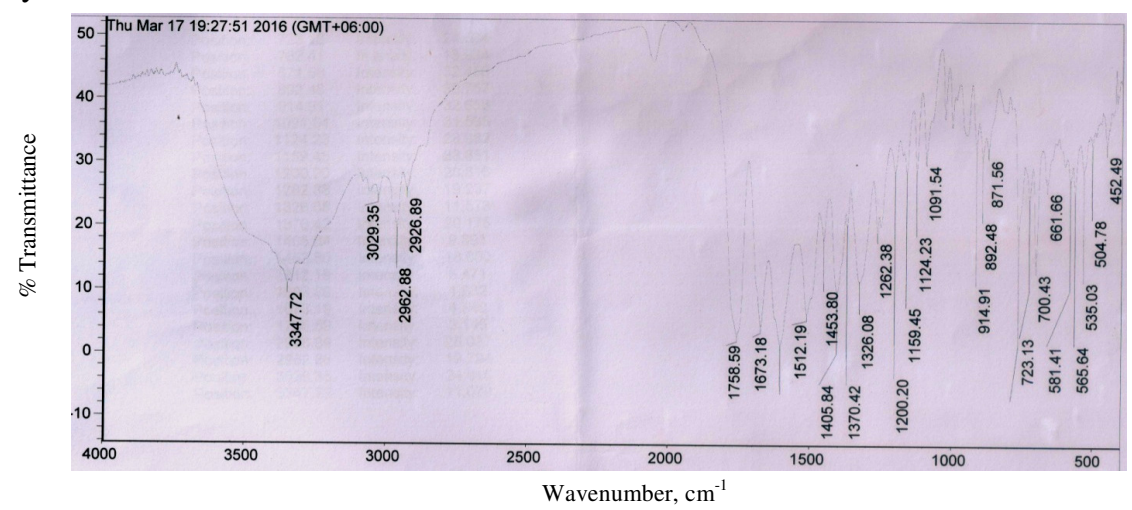

Figure 4. FT-IR spectrum of ampicillin free ligand

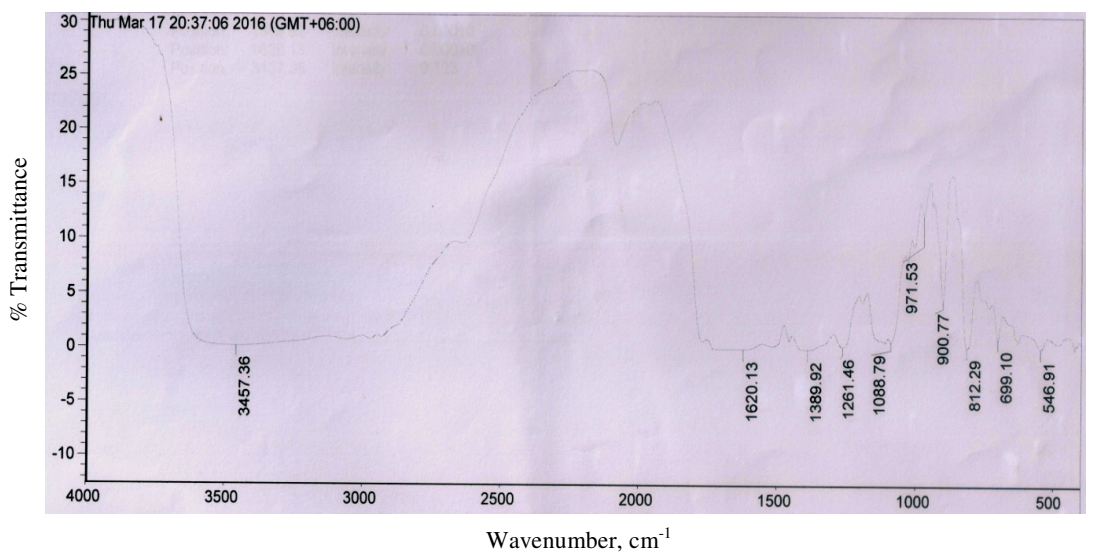

Figure 5. FT-IR spectrum of ampicillin chromium complex

\section{${ }^{1}$ H NMR spectra}

The ${ }^{1} \mathrm{H}$ NMR spectral data ${ }^{31}$ of ampicillin free drug (Figure 6) has been assigned as $\delta$ (ppm) $1.55(6 \mathrm{H}$, two methyl group of dimethyl thiazolidine ring), $4.85(\mathrm{H} ; \mathrm{CH}$ group $), 4.72(1 \mathrm{H}$; thiazolidine ring), $8.03(\mathrm{H}$; $\mathrm{NH}$ of the amide group), 4.86, $5.19(2 \mathrm{H} ; \beta$-lactam $), 7.23,7.33$, $7.26\left(5 \mathrm{H}\right.$; benzene ring), $11.00(1 \mathrm{H} ; \mathrm{COOH})$ and $5.11\left(2 \mathrm{H} ; \mathrm{NH}_{2}\right)$. The ${ }^{1} \mathrm{H}$ NMR spectral data of the $\mathrm{Cr}(\mathrm{III})$ complex has been assigned as $\delta(\mathrm{ppm}), 1.28(6 \mathrm{H}$, two methyl group of dimethyl thiazolidine ring), $7.41(\mathrm{H}$; $\mathrm{NH}$ of the amide group and $5 \mathrm{H}$; benzene ring). Aliphatic C-H protons are seen at 0.84-1.55 ppm.

\section{Antimicrobial study using Agar disk-diffusion method}

Preliminary screening for antimicrobial activities of the stock solutions of the ligand and metal complexes were performed qualitatively using the Agar disk-diffusion method. In vitro antimicrobial activities were measured from the diameter of clear inhibition zones caused by samples against the same bacteria and under the identical experimental conditions. An inoculum suspension of micro organism was swabbed uniformly to solidified nutrient agar in 
Petri dish for bacteria and the inoculum was allowed to dry for $5 \mathrm{~min}^{32}$. Holes of $6 \mathrm{~mm}$ in diameter were made in the seeded agar using cotton swab. The test solutions at a concentration of 500 and $250 \mu \mathrm{g} / \mathrm{mL}$ were added into each well on the seeded medium and allowed to stand on the bench for $1 \mathrm{~h}$ for proper diffusion and thereafter incubated at $37{ }^{\circ} \mathrm{C}$ for $24 \mathrm{~h}$. The resulting inhibition zones were measured in millimeters $(\mathrm{mm})$ (Table 4$)$.

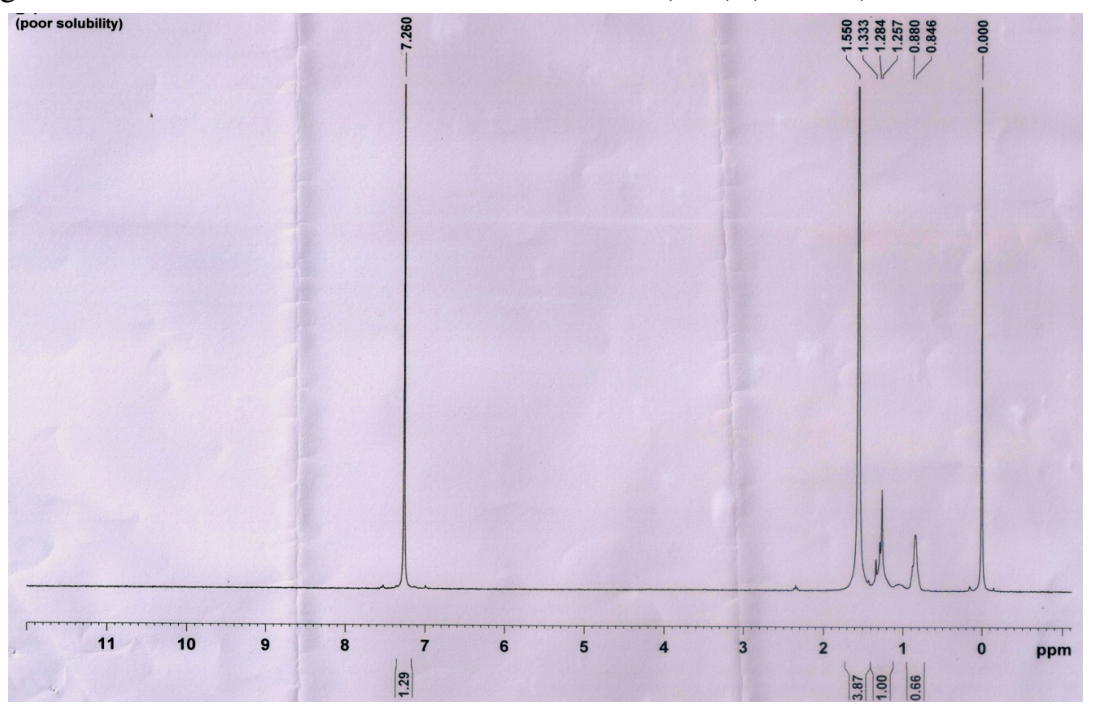

Figure 6. ${ }^{1} \mathrm{H}$ NMR spectrum of complex

The investigation of antimicrobial activities of metal complexes (Figure 7) revealed that the inhibitory ability of the metal complexes is notably higher than the ligand. Antimicrobial activity of the metal chelates can be explained on the basis of chelation theory which may enhance the biochemical potential of a bioactive species. This may be because of chelation, the polarity of the metal ion will be reduced due to the overlap of the ligand orbital and partial sharing of the positive charge of the metal ion with donor groups. This may enhance the penetration of the complex into the lipid membranes enabling it to block the metal binding sites in the enzymes of micro-organisms.

Table 4. Antimicrobial effect of ampicillin and ampicillin chromium complex

\begin{tabular}{ccccc}
\hline Organism & $\begin{array}{c}\text { Ampicillin } \\
500 \mu \mathrm{g} / \mathrm{mL}\end{array}$ & $\begin{array}{c}\text { Ampicillin } \\
250 \mu \mathrm{g} / \mathrm{mL}\end{array}$ & $\begin{array}{c}\text { Ampicillin-Cr } \\
\text { complex } \\
500 \mu \mathrm{g} / \mathrm{mL}\end{array}$ & $\begin{array}{c}\text { Ampicillin-Cr } \\
\text { complex } \\
250 \mu \mathrm{g} / \mathrm{mL}\end{array}$ \\
\hline $\begin{array}{c}\text { Proteus } \text { vulgaris } \\
(\text { NCIM 2027) }(-V E)\end{array}$ & $31.6 \pm 1.8$ & $31.4 \pm 1.6$ & $28.3 \pm 1.4$ & $24.3 \pm 1.8$ \\
$\begin{array}{c}\text { Escherichia coli } \\
(\text { NCIM 2831) }(-V E)\end{array}$ & $34.3 \pm 2.4$ & $28.3 \pm 1.8$ & $28.6 \pm 1.6$ & $22.6 \pm 1.8$ \\
$\begin{array}{c}\text { Pseudomonas } \text { aeruginosa } \\
(\text { NCIM 2037) }(-V E)\end{array}$ & $26.6 \pm 2.2$ & $23.3 \pm 2.2$ & $21.2 \pm 2.4$ & $2.6 \pm 0.75$ \\
$\begin{array}{c}\text { Staphylococcus aureus } \\
(\text { NCIM 2654) }(+V E)\end{array}$ & $35.0 \pm 1.4$ & $28.2 \pm 2.1$ & $23.3 \pm 1.2$ & $18.6 \pm 1.6$ \\
$\begin{array}{c}\text { Bacillus cereus } \\
(\text { NCIM 2461) }(+V E)\end{array}$ & $23.6 \pm 1.6$ & $21.3 \pm 1.2$ & $20.3 \pm 1.2$ & $10.2 \pm 1.4$ \\
$\begin{array}{c}\text { Enterococcus faecalis } \\
(\text { NCIM 2352) }(+V E)\end{array}$ & $27.6 \pm 1.2$ & $22.2 \pm 1.3$ & $16.4 \pm 1.8$ & $13.6 \pm 1.2$ \\
\hline
\end{tabular}




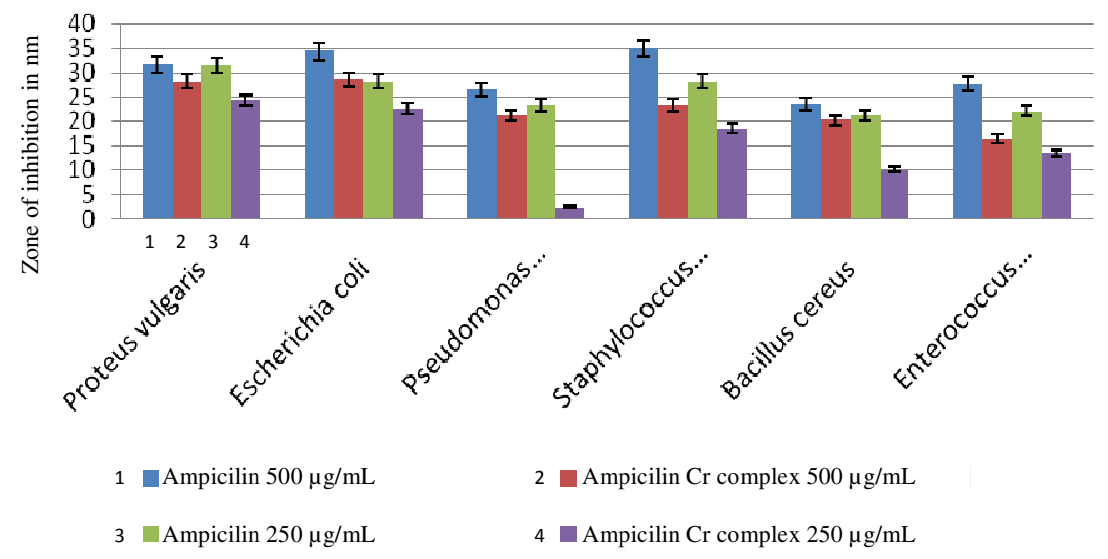

\section{Conclusion}

Figure 7. Antimicrobial study of ampicillin-Cr(III) complex

Kinetic and pharmaceutical study of a new complex of $\mathrm{Cr}(\mathrm{III})$ with the antibiotic drug ampicillin was investigate. From the kinetic measurement, it is cleared that a complex of cis$\left[\mathrm{Cr}\left(\mathrm{C}_{2} \mathrm{O}_{4}\right)_{2}\left(\mathrm{H}_{2} \mathrm{O}\right)_{2}\right]^{-}$with AMP-Na salt is formed via associative mechanism. But solid state identification of the product found out to a dimer. The antibiotic studies of the product show a more effectiveness of the drug ampicillin when bound to $\mathrm{Cr}(\mathrm{III})$.

\section{Acknowledgement}

We authors thank to UGC, Government of India, New Delhi for providing UGC-BSR (Basic Science Research) Fellowship. We are grateful to Central Drug Research Institute, Lucknow for supporting NMR study and CHN analysis and Sri Vasavi Institute of Pharmaceutical Sciences, Tadepaligudem, Andhra Pradesh for antimicrobial study.

\section{References}

1. Nishi K K, Antony M and Jayakrishnan A, J Pharm Pharmacol., 2007, 59(4), 485493; DOI:10.1211/jpp.59.4.0002

2. Hauser A R, Lippincott Williams and Wikins, Antibiotic Basics for Clinicians. 2013, 25.

3. Akova M, Clin Microbiol Infect., 2008, 185-188; DOI:10.1111/j.14690691.2007.01847.x

4. Petri W A, Brunton L L, Chabner B A and Knollmann B C, Goodman and Gilman's the Pharmacological Basis of Therapeutics; $12^{\text {th }}$ Ed., Mc Graw-Hill: New York, 2011; Chapter 53.

5. Cavaglioni A and Cini R, J Chem Soc Dalton Trans., 1997, 1149-1158; DOI:10.1039/A606590B

6. Kenawi I M, Barsoum B N and Youssef M A, J Pharm Biomed Anal., 2005, 37(4), 655-661; DOI:10.1016/j.jpba.2004.10.051

7. Anderson R A, Nutr Res Rev., 2003, 16(2), 267-275; DOI:10.1079/NRR200366

8. Vincent J B, J Nutr., 2000, 130(4), 715-718.

9. Sulfab Y and Al-Jallal N A, Trans Met Chem., 2004, 29(2), 216-220.

10. Kallen T W and Senko E J, Inorg Chem., 1983, 22(20), 2924-2931; DOI:10.1021/ic00162a032

11. Sakagami N, Kita E, Kita P, Winsniewska and Kaizaki S, Polyhedron, 1999, 18(15), 2001-2007; DOI:10.1016/S0277-5387(99)00088-1 
12. Khalek A and Hafeez M, J Pharma Care Health Sys., 2015, 2; DOI:10.4172/23760419.S1.006

13. Richards F M, Wyckoff H M and Allewel N M, Neurosciences, 1969, 901.

14. Ming L J, Med Res Rev., 2003, 23(6), 697-762; DOI:10.1002/med.10052

15. Mertz W, Physiol Rev., 1969, 49,(2) 163-239.

16. Mertz W, Science. 1981, 213(4514), 1332-1338.

17. Mertz W, Toepfer E W, Roginski E E and Polansky M M, Fed Am Soc Exp Biol., 1974, 33, 2275-2280.

18. Anderson R A and Mertz W, Sci Total Environ., 1981, 17(1), 13-29; DOI:10.1016/0048-9697(81)90104-2

19. Anderson R.A, Proc Chromate Symp, Industrial Health Foundation Inc, 1981, 333-340.

20. Thomas G, Medicinal Chemistry; John Wiley and Son ltd: London, 2003, 256.

21. Mukharjee G N and Ghosh T K, Ind J Chem., 1991, 30A, 1033-1037.

22. Dash S C, Brahma G S, Das R, Das N N and Mohanty P, Indian J Chem., 2006, 45A, 2406.

23. Prasad D R, Ramasami T, Ramaswamy D and Santappa M, Inorg Chem., 1982, 21(3), 850-854; DOI:10.1021/ic00133a002

24. Georg B, Handbook of Preparative Inorganic Chemistry; $2^{\text {nd }}$ Ed., Academic Press $1965,2,1372$.

25. Schenk C, Stieger H and Kelm H Z, Anorg Allg Chem., 1972, 391, 1.

26. Frost A A and Peasron R G, Kinetics and Mechanism; Wiley: NewYork, 1961.

27. Nakamoto K, Infrared and Raman Spectra of Inorganic and Coordination Compounds; Wiley: New York, 1997.

28. Deacon G B and Phillips R J, Coord Chem Rev., 1980, 33(3), 227; DOI:10.1016/S0010-8545(00)80455-5

29. Pavia D L, Lampman G M and Kriz G S, Introduction to Spectroscopy; $3^{\text {rd }}$ Ed.; Brooks Cole: USA, 2000.

30. Ross S D, Inorganic Infrared and Raman Spectra; Mc Graw Hill: London, 1972.

31. Al-Khodir F and Refat M, J Pharm Innov., 2015, 10(4), 335-347.

32. Obeidat M, Shatnaw M, Al-alawi M, Al-Zu`bi E, Al-Dmoor H, Al-Qudah M, ElQudah J and Otri I, Res J Microbiol., 2012, 7, 59-67; DOI:10.3923/jm.2012.59.67 